\title{
ATTEMPTED THERAPY AND PROPHYLAXIS OF CRYPTOSPORIDIOSIS IN CALVES BY ADMINISTRATION OF SULPHADIMIDINE
}

\author{
O. FISCHER \\ Veterinary Research Institute, 62132 Brno \\ Received May 19, 1983
}

\begin{abstract}
Fischer O.: Attempted Therapy and Prophylaxis of Cryptosporidiosis in Calves by Administration of Sulphadimidine. Acta vet. Brno, 52, 1983: 183-190.

In an attempt to control natural infection of calves with coccidia of the genus Cryptosporidium Tyzzer, 1910, sulphadimidine was administered to calves aged 1 to 10 weeks prophylactically as a 21 drench at a daily dose of $30 \mathrm{mg} / \mathrm{kg}$ body mass for two 7-day courses seven days apart or at a daily dose of $40 \mathrm{mg} / \mathrm{kg}$ body mass for 14 and 7 days at an interval of 6 days or therapeutically as a 11 drench at a daily dose of $200 \mathrm{mg} / \mathrm{kg}$ body mass for three 3-day courses three days apart. These treatments had practically no effect on cryptosporidia infection, occurrence of diarrhoea and gains in body mass. In the herd under study the proportion of calves shedding cryptosporidia was rather high but the cryptosporidial burden was low. The predominant picture was light infection with irregular shedding of oocysts without clinical sings of disease. Besides cryptosporidial oocysts, faecal examination revealed cysts of flagellates of the genus Giardia Künstler, 1882.
\end{abstract}

Cryptosporidium, Giardia, calf diarrhoea, body mass gain, flotation methods.

Coccidia of the genus Cryptosporidium are regarded as one of possible causes of diarrhoea in calves, whether occurring in combination with enteropathogenic Escherichia coli, rotaviruses and coronaviruses (Morin et al. 1976; Nagy et al. 1980) or in herds where no other known causative agents of diarrhoeal disease were detected (Tzi p or i et al. 1980). Nag y et al. (1980) using sulphoquinoxaline plus polymyxin therapy in a herd where enteropathogenic $E$. coli and cryptosporidia were detected reported reduced mortality and improved general health of the calves. Previous therapy in this herd with polymyxin alone proved unsuccessful, atlhough $E$. coli were sensitive to polymyxin. Preventive administration of sulphadimidine against natural infection of calves with coccidia of the genus Eimeria was reported to produce a rise in average daily gain in body mass by $0.2 \mathrm{~kg}$ (Čeleda et al. 1980). Boch and Supperer (1977) recommended sulphonamides for treatment of coccidioses including cryptosporidiosis. Moon et al. (1982) testing the efficiency of sulphadimidine in calves infected experimentally with cryptosporidia could not prevent the development of infection.

The present study was designed to test the effect of sulphadimidine in the treatment of cryptosporidiosis and to find whether the development of infection can be prevented if sulphadimidine is administered to calves before Cryptosporidium oocysts appear in the faeces.

\section{Material and Methods}

Fifty-nine calves ( 31 heifers and 28 bull calves) of mixed breed (Holstein - Bohemian Pied Red Pied Lowland) kept in a calf house of the co-operative farm ,JZD Rudé armády“, Hustopeče (district Břeclav), were subjected to regular faecal examination. The mode of calf rearing in this calf house has been described by Menšík and Salajka (1975) and Menšík et al. (1977). Calves originating from three neighbouring cow houses were separated from the dams immediately after 
birth and moved to the calf house where housed in 8 rooms of 25 stanchion-type straw-bedded stalls up to 90 days of age. The rooms were cleaned twice daily. The calves were fed colostrum from their dams during the first 8 days and then milk replacers Laktosan A from 9 to 25 days and Laktosan B from 26 to 40 days of age. From the 41 st day they received Laktosan B diluted progressively with water and were then changed to a vegetable diet at 60 days of age. The rooms were operated under the all-in all-out system. After all calves housed in a room were removed, the room was disinfected with hot vapour under pressure (temperature above $60^{\circ} \mathrm{C}$ ) and 3 per cent chloramine solution (temperature 45 to $50^{\circ} \mathrm{C}$ ) and left vacant for 10 days before new arrivals were moved in. Each room was a self-contained unit, to which only attendants and the veterinarian had access, and housed calves of approximately the same age. However, an age difference of 1 to 90 days was between calves in the room housing the latest arrivals and those in the room housing calves that were brought in earliest. Calves in all the 8 rooms were cared for by the same attendants who came from one room to another. The corridor and the ramp serving for manure removal and fresh straw supply were common to all the rooms. Each calf was fed from its own vessel. Although the stanchion-type stalls were separated from each other by plywood partitions, the calves could turn round and come into contact with the neighbouring animals. Disinsection was carried out once every three months. During the period under study several common mice (Mus musculus) were caught. They had been brought to the calf house with fresh straw which was supplied twice daily. Rotaviruses, coronaviruses, enteropathogenic $E$. coli and occasional cryptosporidia were demonstrated in the herd already in the first weeks after birth (Š ťpánek et al. 1981).

The 59 calves included in the present study were subjected to faecal examination in the 1st to 10 th weeks of age. Further examinations were not possible for technical reasons. Faeces were collected from the rectum into plastic bottles provided with lids at 3-to 5-day intervals. The animals were observed at the same time for the appearance of diarrhoea. The faeces were stored at $+4{ }^{\circ} \mathrm{C}$ and processed within two days of collection.

Faecal examinations were carried out using Breza's flotation method (Breza 1959) combined with washing of the surface film with water immediately after flotation (Fischer 1982). Immediately afterwards 5 loopfuls (loop $4 \mathrm{~mm}$ in diameter) of the surface film were transferred to a conical-bottom centrifuge tube filled with water. The tube was centrifuged at $3000 \mathrm{rpm}$ for two minutes, the supernatant was discarded and the sediment was dispersed in a drop of water that had run down along the tube wall. The resultant drop of suspension was poured onto a microscope slide, spread with a loop over an area of 3 sq. $\mathrm{cm}$ and examined with a light microscope at 100, 250 and 630 times magnification. The cryptosporidial burden was graded at 250 times magnification as follows: $+=$ light infection ( 1 to 5 oocysts in the smear) $;++=$ moderate infection ( 6 to 10 oocysts); and $+++=$ heavy infection (11 or more oocysts). The Giardia burden was graded at 250 times magnification as follows: $+=$ light infection ( 1 to 5 cysts in the microscopic field); $++=$ moderate infection (6 to 20 cysts); and $+++=$ heavy infection ( 21 or more cysts).

The calves under study were divided according to age into three groups housed in three separate rooms. Each group was divided into two sex- and birth-body-mass-matched subgroups, one of which was placed on therapy or preventive treatment with sulphadimidine and the other served as controls.

Group 1 (16 calves) consisted of 8 naturally infected calves treated with sulphadimidine (Sulfadimidin Spofa pulv. solub.) and 8 untreated controls. Sulphadimidine was given as a 11 drench a daily dose of $200 \mathrm{mg}$ per $\mathrm{kg}$ body mass for three 3-day courses of treatment three days apart. The treatment was started in the 2 nd week of age after cryptosporidial oocysts were first observed in the faeces of two calves at 1 week of age. The experimental design for Groups 2 and 3 was guided by our previous observation that calves of this herd shed first oocysts in their faeces in the second week after birth (Fischer 1982). Sulphadimidine was therefore administered prophylactically from the first week of age before oocysts were first observed in the faeces (Table 2).

Group 2 ( 22 calves) consisted of 11 calves given sulphadimidine as a 21 drench from the first week of age at a daily dose of circa $30 \mathrm{mg}$ per $\mathrm{kg}$ body mass for two 7-day courses seven days apart and of 11 untreated controls.

In Group 3 ( 21 calves) sulphadimidine was given prophylactically to 11 calves from the first week of age as a 21 drench at a daily dose of circa $40 \mathrm{mg}$ per $\mathrm{kg}$ body mass for 14 days, then was withdrawn for 6 days and administered again for the next 7 days. The remaining 10 calves served as untreated controls. The effectiveness of sulphadimidine therapy and prophylaxis was evaluated one week after the last administration. Age-dependence of the occurrence of cryptosporidia, Giardia and diarrhoea was followed in the 29 control calves of the three groups under study. All calves were weighed after birth and at the end of the experiment at 70 to 90 days of age. 


\section{Results}

\section{Occurrence of Cryptosporidia in Calves as a Function of Age}

Calves of all the three groups became naturally infected with coccidia of the genus Cryptosporidium Tyzzer, 1910, during the observation period. The overall proportion of infected calves among the 29 controls was 72.4 per cent (Table 1).

Table 1

Relation between the occurrence of cryptosporidia, Giardia and diarrhoea and the age of the calves

\begin{tabular}{|c|c|c|c|c|c|c|c|c|c|c|c|c|}
\hline \multirow{4}{*}{$\begin{array}{c}\text { Calf } \\
\text { age } \\
\text { (weeks) }\end{array}$} & \multicolumn{12}{|c|}{ Faecal findings in 29 control calves } \\
\hline & \multicolumn{5}{|c|}{ Cryptosporidium sp. } & \multicolumn{5}{|c|}{ Giardia sp. } & \multirow{3}{*}{$\begin{array}{c}\text { No. calves } \\
\text { infected } \\
\text { with both } \\
\text { parasites/ } \\
\text { /with } \\
\text { diarrhoea }\end{array}$} & \multirow{3}{*}{$\begin{array}{l}\text { No. ne- } \\
\text { gative } \\
\text { calves } \\
\text { dia- } \\
\text { rrhoea }\end{array}$} \\
\hline & \multirow{2}{*}{$\begin{array}{l}\text { No. calves } \\
\text { positive/ } \\
\text { /with } \\
\text { diarrhoea }\end{array}$} & \multirow{2}{*}{\begin{tabular}{|c|}
$\%$ \\
calves \\
positive
\end{tabular}} & \multicolumn{3}{|c|}{ oocyst score } & \multirow{2}{*}{$\begin{array}{l}\text { No. calves } \\
\text { positive/ } \\
\text { /with } \\
\text { diarrhoea }\end{array}$} & \multirow{2}{*}{$\begin{array}{c}\% \\
\text { calves } \\
\text { posi- } \\
\text { tive }\end{array}$} & \multicolumn{3}{|c|}{ cyst score } & & \\
\hline & & & + & ++ & +++ & & & + & ++ & +++ & & \\
\hline $\begin{array}{r}1 \\
2 \\
3 \\
4 \\
5 \\
6 \\
7 \\
8 \\
9 \\
10\end{array}$ & $\begin{array}{r}0 / 0 \\
4 / 3 \\
12 / 7 \\
5 / 1 \\
6 / 4 \\
2 / 2 \\
2 / 1 \\
5 / 1 \\
0 / 0 \\
0 / 0\end{array}$ & $\begin{array}{r}- \\
13.8 \\
41.4 \\
17.2 \\
20.7 \\
6.9 \\
6.9 \\
17.2 \\
- \\
-\end{array}$ & $\begin{array}{l}-4 \\
8 \\
3 \\
5 \\
2 \\
2 \\
5 \\
- \\
-\end{array}$ & $\begin{array}{r}- \\
4 \\
2 \\
1\end{array}$ & $\begin{array}{l}- \\
\overline{-} \\
- \\
- \\
\overline{-} \\
- \\
-\end{array}$ & $\begin{array}{r}0 / 0 \\
1 / 0 \\
1 / 1 \\
1 / 0 \\
9 / 3 \\
15 / 2 \\
9 / 0 \\
9 / 0 \\
10 / 1 \\
10 / 1\end{array}$ & $\begin{array}{r}\overline{3.4} \\
3.4 \\
3.4 \\
31.0 \\
51.7 \\
31.0 \\
31.0 \\
34.5 \\
34.5\end{array}$ & $\begin{array}{l}1 \\
1 \\
1 \\
4 \\
6 \\
7 \\
7 \\
7 \\
9\end{array}$ & $\begin{array}{c}- \\
\overline{-} \\
- \\
2 \\
4 \\
- \\
1 \\
1 \\
-\end{array}$ & $\begin{array}{l}- \\
- \\
- \\
\overline{3} \\
5 \\
2 \\
1 \\
2 \\
1\end{array}$ & $\begin{array}{l}\overline{-} \\
\overline{1 / 1} \\
\overline{2 / 0} \\
\overline{2 / 0} \\
\overline{-} \\
-\end{array}$ & $\begin{array}{r}6 \\
9 \\
11 \\
9 \\
6 \\
4 \\
2 \\
2 \\
1 \\
0\end{array}$ \\
\hline 10 & \multicolumn{5}{|c|}{$\begin{array}{l}\text { Overall proportion of infected calves: } \\
72.4 \text { per cent }\end{array}$} & \multicolumn{5}{|c|}{$\begin{array}{l}\text { Overall proportion of infected calves: } \\
75.9 \text { per cent }\end{array}$} & & \\
\hline
\end{tabular}

The predominant picture was light infection with irregular shedding of oocysts without clinical signs of disease. Oocysts were found in the faeces from the 2nd to the 8 th week of age, the largest proportion of infected calves (41.4 per cent) and the highest oocyst burden being recorded in the 3rd week after birth. No oocysts were found in the 1st, 9th and 10th weeks after birth. In sulphadimidinetreated calves oocysts were first observed in the faeces of two calves of Group 1 as early as the 1st week after birth. One of these calves had diarrhoea (Table 2). One calf was heavily infected and developed diarrhoea before treatment at two weeks of age. The course of infection in sulphadimidine-treated calves showed little difference from that seen in the controls. Occasional oocysts after sulphadimidine treatment were found in the 8 th to 10 th weeks after birth.

\section{Effectiveness of Sulphadimidine}

In Group 1 the proportion of infected calves among experimental animals before sulphadimidine treatment was 25.0 per cent (Table 2). The occurrence of cryptosporidia decreased gradually from the $3 \mathrm{rd}$ week of age (Table 1); the last oocysts were found in the 7th and 8th weeks after birth. The proportion of infected calves after sulphadimidine treatment was 12.5 per cent in both the treated and untreated animals (Table 2). The value for extensive effectiveness (EE) of sulphadimidine (87.5 per cent), i. e. the percentage of animals that shed no oocysts after treatment, is meaningless, since the occurrence of cryptosporidia decreased with advancing age in both the treated and control calves. 
Table 2

Effect of therapeutic and prophylactic sulphadimidine treatments of calves on their faecal shedding of cryptosporidia, occurrence of diarrhoea and average gains in body mass

\begin{tabular}{|c|c|c|c|c|c|c|c|c|c|}
\hline \multirow{3}{*}{ Group } & \multirow{3}{*}{$\begin{array}{l}\text { No. } \\
\text { calves }\end{array}$} & \multirow{3}{*}{$\begin{array}{c}\text { Daily } \\
\text { dose } \\
\text { (mg/kg } \\
\text { body } \\
\text { mass) }\end{array}$} & \multirow{3}{*}{$\begin{array}{l}\text { Application } \\
\text { method and } \\
\text { schedule of } \\
\text { treatment }\end{array}$} & \multicolumn{4}{|c|}{ Faecal cryptosporidia } & \multirow{3}{*}{ EE* } & \multirow{3}{*}{$\begin{array}{l}\text { Av. } \\
\text { daily } \\
\text { gain } \\
\text { (kg) }\end{array}$} \\
\hline & & & & \multicolumn{2}{|c|}{ Before treatment } & \multicolumn{2}{|c|}{ After treatment } & & \\
\hline & & & & $\begin{array}{c}\text { No. calves } \\
\text { positive/ } \\
\text { /with } \\
\text { diarrhoea }\end{array}$ & $\begin{array}{l}\% \text { calves } \\
\text { positive }\end{array}$ & $\begin{array}{l}\text { No. calves } \\
\text { positive/ } \\
\text { /with } \\
\text { diarrhoea }\end{array}$ & $\begin{array}{l}\% \text { calves } \\
\text { positive }\end{array}$ & & \\
\hline \multirow[t]{2}{*}{1} & 8 & 200 & $\begin{array}{l}\text { Drench } \\
\text { Three 3-day } \\
\text { courses } \\
3 \text { days apart }\end{array}$ & $2 / 1$ & 25.0 & $1 / 0$ & 12.5 & \multirow[t]{2}{*}{87.5} & $\begin{array}{l}\text { o } 0.7 \\
\text { ○ } 0.6\end{array}$ \\
\hline & 8 & - & - & $0 / 0$ & 0.0 & $1 / 0$ & 12.5 & & $\begin{array}{l}\text { ô } 0.7 \\
\text { † } 0.6\end{array}$ \\
\hline \multirow[t]{2}{*}{2} & 11 & 30 & $\begin{array}{l}\text { Drench } \\
\text { Two 7-day } \\
\text { courses } \\
7 \text { days apart }\end{array}$ & $0 / 0$ & 0.0 & $0 / 0$ & 0.0 & \multirow[t]{2}{*}{100.0} & 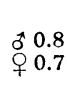 \\
\hline & 11 & - & - & $0 / 0$ & 0.0 & $2 / 0$ & 18.2 & & $\begin{array}{l}00.9 \\
\text { ô } 0.6\end{array}$ \\
\hline \multirow[t]{2}{*}{3} & 11 & 40 & $\begin{array}{l}\text { Drench } \\
14 \text {-day therapy } \\
6 \text { days without } \\
\text { therapy } \\
7 \text {-day therapy }\end{array}$ & $0 / 0$ & 0.0 & $3 / 1$ & 27.3 & \multirow[t]{2}{*}{72.7} & $\begin{array}{l}\text { ô } 0.6 \\
\text { ధ્ } 0.6\end{array}$ \\
\hline & 10 & - & - & $0 / 0$ & 0.0 & $3 / 1$ & 30.0 & & $\begin{array}{l}0.0 .7 \\
\text { ô } 0.6\end{array}$ \\
\hline
\end{tabular}

* $\mathrm{EE}=$ extensive effectiveness, i. e. the percentage of animals that shed no oocysts after treatment.

In Groups 2 and 3 where sulphadimidine treatment was started prophylactically before cryptosporidia were first observed the post-treatment results were as follows: In Group 2 no treated calves shed oocysts as against 18.2 per cent of infected animals among the controls $(\mathrm{EE}=100$ per cent). In Group 3 the proportion of calves shedding oocysts after treatment was 27.3 per cent as against 30.0 per cent in the controls ( $\mathrm{EE}=72.7$ per cent). The decrease in faecal cryptosporidia among sulphadimidine-treated calves was not significantly different from that found in the controls and was therefore caused by advancing age and not by the action of sulphadimidine.

\section{Effect of Sulphadimidine Treatment on Gain in Body Mass}

In Group 1 the average daily body mass gain of the treated and control calves was the same, namely, $0.7 \mathrm{~kg}$ for bull calves and $0.6 \mathrm{~kg}$ for heifers (Table 2). In Group 2 the average daily gain of sulphadimidine-treated bull calves was $0.1 \mathrm{~kg}$ lower and that of sulphadimidine-treated heifers $0.1 \mathrm{~kg}$ higher than in the controls. In Group 3 the average daily gain of sulphadimidine-treated bull calves was $0.1 \mathrm{~kg}$ lower than in the controls, whereas that of heifers was the same $(0.6$ $\mathrm{kg}$ ) in both subgroups. 


\section{Other Parasites}

Oocysts of coccidia of the genera Eimeria and Isospora were not observed. Besides cryptosporidial oocysts, the faeces of the calves of all the three groups were found to contain cysts of flagellates of the genus Giardia Künstler, 1882. In the 29 controls the overall proportion of infected calves was 75.9 per cent (Table 2). Cysts were first found in a 2-week-old calf without clinical signs of disease. The largest proportion of infected calves and the highest Giardia burden were found between the 5 th and 10th weeks of age; in the 6th week the proportion of infected calves amounted to 51.7 per cent. The course of infection in sulphadimidine-treated calves showed little difference from that seen in the controls. Thin- and smooth-walled ovoid cysts $(12.0-14.2 \times 8.0-10.1 \mu \mathrm{m}, \mathrm{n}=50$, mean $13.9 \times 9.9 \mu \mathrm{m}$ ) with a cytoplasm having a light blue appearance were found most frequently in the faeces of normal consistency and rarely in watery or mucoid faeces. Trophozoites were not observed.

Solitary nematode (Strongyloides papillosus) eggs were found in the faeces of two calves at 8 and 10 weeks of age.

\section{Discussion}

From the results of mass examination of live and dead calves conducted by Heine and Boch (1981) in the German Federal Republic it appears that cryptosporidial oocysts may be excreted in the faeces of not only diseased but also clinically healthy calves. In our study we encountered, for the most part, light infections not accompanied by diarrhoea.

The dependence of the clinical course of disease upon the age at which animals are infected was described by Tzipori et al. (1981). Having infected lambs of varying ages with cryptosporidial oocysts from faeces passed by calves, these investigators found that clinical signs were most severe in lambs infected up to the 5th day after birth, whereas lambs infected between 20 and 30 days of age did not develop diarrhoea or other signs of disease and shed oocysts irregularly for short periods of time. In our study in calves, light infections with irregular faecal shedding of oocysts were predominant. Infection was first observed at 2 weeks of age. One two-week-old calf showed heavy infection accompanied by profuse diarrhoea. The largest proportion of infected calves and the highest cryptosporidial burden were recorded between 2 and 4 weeks of age; the occurrence of diarrhoea reached its peak at the same time. Tzipori et al. (1982) tested the efficiency of sulphadimidine and sulphamethazine in mice infected experimentally with cryptosporidia isolated from calves and found them ineffective. In our study on the efficiency of sulphadimidine against cryptosporidia in naturally infected calves we attempted to prevent the development of infection in the early stage and sulphadimidine administration was therefore started before the majority of calves shed oocysts in their faeces. Consequently, the proportion of infected calves before sulphadimidine administration was invariably very low to nil. During the period of sulphadimidine administration little difference was found in the course of infection between the treated and untreated subgroups and the post-treatment evaluation of sulphadimidine was carried out at a time when the proportions of infected animals decreased with advancing age. In consequence, the efficiency of sulphadimidine against cryptosporidia could not be demonstrated. The values for $\mathrm{EE}$ of 72.7 to 100 per cent are to be accounted for by a natural 
decrease in the proportions of infected calves with advancing age and not by the effect of sulphadimidine. The treatment had practically no effect on average gains in body mass. Therefore sulphadimidine in the doses used in the present study cannot be recommended for either therapy or preventive treatment of cryptosporidiosis.

Having found that, besides cryptosporidial oocysts, the faeces of calves in our study often contained cysts of flagellates of the genus Giardia we investigated their occurrence in relation to the age of the calves and in comparison with the appearance of diarrhoea.

Supperer (1952) described the finding of large numbers of Giardia cysts $(9-16 \times 7-10 \mu \mathrm{m})$ in the mucoid faeces of a 31-day-old bull calf with chronic catarrhal duodenitis and jejunitis. Botti (1956) reported the first finding of Giardia bovis Fantham, 1921, in Italy in calves with haemorrhagic enteritis; the cysts were $8.5 \times 5.6 \mu \mathrm{m}$ in size. Desphande and Shastri (1981) found Giardia cysts $(12.5-14.6 \times 8.7$ to $10.4 \mu \mathrm{m})$ in 81 (51.6 per cent) of 157 calves examined at 1 to 6 months of age. The measurements of Giardia cysts found in our study are similar to those described by Supperer (1952) and Deshpande and Shastri (1981) but differ from the data reported by Botti (1956).

In the present study using Breza's flotation method in combination with washing of the surface film with water no trophozoites were detected in the faeces and therefore Giardia could not be classified as to species. Wils on (1982) reported giardiasis in two calves aged 13 and 42 days; both of them ceased passing mucoid gassy faeces after treatment with atabrine hydrochloride.

In calves observed in our study from 1 to 10 weeks of age Giardia infection was first detected at two weeks of age in one calf and the largest proportion of infected animals and the highest Giardia burden were found in the 6th week after birth but infections without clinical signs were predominant.

Whereas the incidence of cryptosporidia rose and fell with the occurrence of diarrhoea, the incidence of Giardia reached ist peak after the occurrence of diarrhoea had markedly decreased.

\section{Léčebné a preventivní podávání sulfadimidinu proti kryptosporidióze telat}

U telat ve věku $1-10$ týdnů byl sledován účinek sulfadimidinu proti přirozené invazi kokcidiemi rodu Cryptosporidium Tyzzer, 1910. Sulfadimidin byl podáván preventivně terapeuticky ve 21 nápoje $\mathrm{v}$ denní dávce $30 \mathrm{mg}$ na $\mathrm{kg} \check{z}$. h. dvakrát po dobu 7 dnů v odstupu 7 dnů nebo v denní dávce $40 \mathrm{mg}$ na $\mathrm{kg}$ ž. h. po dobu 14 a 7 dnů $v$ odstupu 6 dnů nebo léčebně v 11 nápoje $v$ denní dávce $200 \mathrm{mg}$ na $\mathrm{kg}$ ž. h. třikrát po dobu tř́ dnů s tř́denními odstupy. Podávání sulfadimidinu neovlivnilo invazi kryptosporidiemi, výskyt průjmů ani hmotnostní prírůstky telat. Kryptosporidióza v tomto chovu se vyznačovala vysokou extenzitou a nízkou intenzitou invaze; převládaly slabé invaze $s$ nepravidelným vylučováním oocyst, často bez klinických př́znaků onemocnění. U telat byla zjištěna rovněž invaze bičíkovci rodu Giardia Künstler, 1882. 


\section{Лечебная и профилактическая подача сульфадимидина от криптоспоридиоза телят}

У телят в возрасте 1-10 недель проводились наблюдения за воздействием сульфадимидина против естественной инвазии кокцидиями рода Cryptosporidium Tyzzer, 1910. ' Сульфадимидин подавали профилактически терапевтически в 2 литрах пойла суточной дозой 30 мг на 1 кг живого веса два раза в течение 7 дней в интервале недели или суточной дозой 30 мг на 1 кг живого веса в течение двух недель и одной недели в интервале 6 дней, а также лечебно в 1 литр пойла суточной дозой 200 мг на 1 кг живого веса три раза в течение трех дней с трехдневными интервалами. Подача сульфадимидина не оказала влияния на инвазию криптоспоридиями, на наличие поносов, ни на весовой прирост телят. Криптоспоридиоз в данной разводке отличался высокой экстенсивностью и низкой интенсивностью инвазии; преобладающими стали слабые инвазии с нерегулярным выделением оокист, зачастую без клинических признаков заболевания. У телят была также установлена инвазия жгутиковыми рода Giardia Künstler, 1882.

\section{Acknowledgement}

The skilled technical assistance of Mrs. V. Juříčková is highly appreciated.

\section{References}

BOCH, J. - SUPPERER, R.: Veterinärmedizinische Parasitologie. Berlin, Hamburg 1977, pp. 498. BOTTI, L.: Prima segnalazione in Italia della giardiasi del vitello. Indagini biometriche sul parassita e sua identificatione nella specie Giardia bovis Fantham, 1921. Riv. Parasit., Roma, 17, 1956: 129-142.

BREZA, M.: Zlepšenie metodiky koproovoskopického vyšetrenia trusu ošípaných s použitím nového flotačného roztoku a mukogélu (Mucogel lig.). Vet. Čas., 8, 1959: 569-577.

ČELEDA, L. - RAŠKOVÁ, H. - URBANOVÁ, Z. - ČERNÝ, J. - PAVLÁSEK, I. KUBÍČEK, A. - POLÁK, L.: Léčení kokcidiózy telat $\mathrm{v}$ období mléčné výživy. Veterinářství, 32, 1982: $25-26$.

DESHPANDE, P. D. - SHASTRI, U. V.: Incidence of Giardia infection in calves in Maharashtra state, India. Trop. Anim. Hlth Prod., 13, 1981: 34.

FISCHER, O.: Kryptosporidióza telat v období mléčné výživy. Vet. Med., Praha, 27, 1982: $465-471$.

HEINE, J. - BOCH, J.: Kryptosporidien-Infektionen beim Kalb. Nachweis, Vorkommen und experimentelle Übertragung. Berl. Münch. tierärztl. Wschr., 94, 1981: 298-292.

MENŠÍK, J. - SALAJKA, E.: Výzkum veterinární prevence a zdraví telat. (Project report).

Brno, Veterinary Research Institute 1975, $52 \mathrm{p}$.

MENŠÍK, J. - DRESSLER, J. - FRANZ, J.: Pokus o prevenci respiračního syndromu odchovem telat s minimální nemocností. Vet. Med., Praha, 22, 1977: 463-474.

MOON, H. W. - WOODE, G. N. - AHRENS, F. A.: Attempted chemoprophylaxis of cryptosporidiosis in calves. Vet. Rec., 110, 1982: 181.

MORIN, M. - LARIVIẼRE, S. - LALLIER, R.: Pathological and microbiological observations made on spontaneous cases of acute neonatal calf diarrhea. Can. J. comp. Med., 40, 1976: 228 to 240 .

NAGY, B. - ANTAL, Á. - LAKNER, J.: Significance of intestinal cryptosporidiosis in calf diarrhea. Proc. 2nd Int. Symp. Vet. Lab. Diagnosticians. Luzern 1980, 431-434.

SUPPERER, R.: Über die Lambliose (Giardiose) des Rindes. Wien. tierärztl. Mschr., 39, 1952 : $26-29$.

ŠTĚPÁNEK, J. - PŠIKAL, I. - MENŠÍK, J. - SALAJKA, E. - FRANZ, J. - CHROUSTOVÁ, E. - MENŠ́́, P. - POSPÍŠIL, Z. - SALAJKOVÁ, Z. - SVOBODA, I. ŠMÍD, B. - TOMAN, M. - VALÍČEK, L.: Analýza přičin gastroenteritid novorozených telat. (Project report). Brno, Veterinary Research Institute 1981, 32 p. 
TZIPORI, S. - CAMPBELL, I. - SHERWOOD, D. - SNODGRASS, D. R. - WHITELAW, A.: An outbreak of calf diarrhoea attributed to cryptosporidial infection Vet. Rec., 107, 1980: $579-580$.

TZIPORI, S. - ANGUS, K. W. - GRAY, E. W. - CAMPBELL, I. - ALLAN, F.: Diarrhea in lambs experimentally infected with Cryptosporidium isolated from calves. Am. J. vet. Res., 42, 1981: $1400-1404$.

TZIPORI, S. - CAMPBELL, I. - ANGUS, K. W.: The therapeutic effect of 16 antimicrobial agents on Cryptosporidium infection in mice. Aust. J. exp. Biol. med. Sci., 60, 1982: 187-190. WILLSON, P. J.: Giardiasis in two calves. Can. vet. J., 23, 1982: 83. 